\title{
System-Based Assessment Implementation Schoology
}

\author{
Dadang Saepuloh ${ }^{1}$, Mailisa Setianingsih ${ }^{2}$, Andi Yustira Lestari Wahab ${ }^{3}$ \\ \{dsaepuloh@unis.ac.id ${ }^{1}$, mailisasetianingsih@gmail.com²\} \\ ${ }^{1,2,3}$ FKIP Ekonomi Universitas Islam Syekh Yusuf, Banten, Indonesia
}

\begin{abstract}
This study aims to analyze the mechanism for implementing schoology-based assessment in SMA Negeri 10 Kota Tangerang. The research method that the researcher uses is a qualitative method of the type of case study. The subjects in this study were teachers and students in SMA Negeri 10 Kota Tangerang. Informants in this study consisted of teachers including the subject, and students. Data collection in this study used observation techniques and open interview techniques. Checking the validity of the data in this study uses triangulation techniques and sources. Data is analyzed qualitatively. The results of this study indicate that the implementation of schoology system-based assessments at SMA Negeri 10 Kota Tangerang is carried out systematically with media facilities and infrastructure complete with adequate implementation of schoology-based assessment, the application of schoology systems has a positive impact on the application system-based assessment process for the school because the assessment process becomes more effective and efficient. This study concluded that an effective outcome of the assessment can be used to improve the motivation of the learning of students.
\end{abstract}

Keywords: E-Learning, Evaluation, Schoology

\section{Introduction}

The development of science and technology is increasingly growing rapidly, especially in information technology systems that provide various positive impacts on the advancement of the world of education. The learning process in the 21 st century education transformation era is a learning process to demand changes in the learning paradigm (Trilling \& Fadel, 2009), said that in the 21 st century education must always move in line with the progress of the era of this movement based on changes in the paradigm of education from the conventional to modern education (Afandi, Junanto, \& Afriani, 2016). The development used in E-learning is in the form of a Learning Management System (LMS). This LMS is a website-based integrative learning management system (Firmansyah, 2015). The LMS that has been used until now has many kinds. Starting from Moodle, Claroline, Atutor, eFront, Schoology, and many others. Schoology is a Learning Management System (LMS) for schools where visual and functional are easy to use just like Facebook social media, services that can be used in the form of attendance records, online grade books (facilities for managing grades), tests and quizzes, and homework. Schoology is also provided in the form of mobile phone applications with internet access (Garcia, Amat \& Colomina, 2018). Media Schoology allows teachers to conduct classes with students outside the classroom such as conduct and monitor the course of the discussion through the media Schoology and students can contribute directly therein. The advantages of 
Schoology media are supported by various forms of learning support media such as video, audio, and images that can attract students' attention to learning activities. Schoology directs students to apply the use of technology in learning (Sicat, 2015).

Based on the results of previous studies in "Blended learning based on schoology: Effort of improvement learning outcome and practicum chance in vocational high school", they revealed that there were differences in learning outcomes between Blended Learning based on Schoology and Problem-Based Learning and there were differences in learning outcomes between students with high, medium, and low-edge knowledge and no interaction between Blended Learning based on Schoology and prior knowledge for results study (Irawan, Sutadji, \& Widiyanti, 2017). Online student activities in media schoology (students studying online outside of school hours / at home) do not experience an increase in activity and tend to decrease due to technical and non-technical factors as presented in the results chapter and discussion in this study (Ulva, Kantun, \& Widodo, 2017). Whereas there are other studies showing that implementing e-learning with media Schoology can increase student motivation and learning outcomes on basic competencies (Aminoto \& Pathoni, 2014).

\section{Theoretical Support}

Evaluation refer to the act or process to determining the value of something. Edwind Wandt dan Gerald W. Brown (1997). Evaluation is also one component of the learning / education system. This means, evaluation is the main activity in every activity or process of learning.

The good side of using e-Learning is that students are required to be more active than traditional teaching. Providing a path to a student center learning system (Sohibun \& Ade, 2017). E-learning provides new hope as an alternative solution to most education problems in Indonesia, with functions that can be adapted to needs, either as supplements (additions), complement (complimentary), or substitution (substitute) for learning activities in the classroom during this is used (Warsito \& Djuniadi, 2016).

E-learning is now a learning that is quite popular in the world of global education "Overseas like in the United States, e-learning has been used almost $90 \%$ at each level of education units that have more than 10,000 students." (Basori, 2007). Because the benefits were so felt, various types of e-learning development models emerged. Starting from just PowerPointbased in the classroom to the LMS (Learning Management System) system. LMS that has been used until now has many types, one of which is Schoology. Schoology.

Schoology is an online social learning network and interactive learning management system initiated by four students named Jeremy Friedman, Ryan Hwang, Tim Trinidad, and Bill Kindler in 2007. At present, more than seven million users from more than 60,000 K-12 schools and higher education institutions around the world use this learning platform in their classrooms. (Sarrab, Elbasir, \& Alnaeli, 2016).

Schoology is a collaboration and learning tool, a K-12 based web learning media that can facilitate learning for students, parents, and teachers accessible 24/7 in the form of material and all class information via the internet. Schoology is an application that does not require subscription fees and makes it easy to establish teacher communication between teachers, teachers for students, and even students for collaboration with other students online which makes it easy for users and also safe. In addition, schoology also offers the possibility to design collaborative learning as a tool to tailor learning to each student (Farmington Schoology, 2018). 
Schoology is an innovative platform that is built on inspiration from Facebook social media with the aim of educational interests. This platform was developed in 2009 in New York . Schoology can help teachers to open broad communication opportunities to students so that students can more easily take part/role in discussions and teamwork. In addition, Schoology is also supported by various forms of media such as video, audio, and images that can attract students' interest. Schoology directs students to apply the use of technology in learning. The Schoology is a free service that uses the concept of managing social learning which is devoted to building a safe online learning environment for sharing information and educational features or content in the form of writing, files, and links that can be shared by both teachers and students, and also features specifically in the form of courses, groups, and resources (Garcia et al., 2018).

\section{Method}

The research method that the researcher uses is a qualitative method of the type of case study. The subjects in this study were teachers and students in SMA Negeri 10 Kota Tangerang. Informants in this study consisted of teachers including the subject, and students. Data collection in this study used observation techniques and open interview techniques. Checking the validity of the data in this study uses triangulation techniques and sources. Data is analyzed qualitatively. The qualitative study of the case study used is an intrinsic case study, this case study was carried out to better understand in depth the application of schoology applications. In particular, the research approach chosen was a case study, because researchers felt it was most appropriate to use this method to gain a deep understanding of how the image of implementing schoologybased assessment at SMAN 10 Kota Tangerang.

\section{Result And Discussion}

\subsection{Evaluation implements schoology-based assessments in SMA Negeri 10 Kota Tangerang.}

Evaluations carried out at SMA Negeri 10 Kota Tangerang are divided into several aspects carried out through research procedures, the subjects of which are included in the following table:

Table.1 List of Schoology Evaluation Subjects

\begin{tabular}{clc}
\hline NO & \multicolumn{1}{c}{ SUBJECT } & PERCENTAGE \\
\hline 1 & Administration & $90 \%$ \\
2 & Time & $90 \%$ \\
3 & Attendance & $60 \%$ \\
4 & Communication & $70 \%$ \\
5 & Design & $90 \%$ \\
7 & Document Support Format & $90 \%$ \\
8 & Training & $50 \%$ \\
9 & Assessment & $90 \%$ \\
10 & Accessibility & $70 \%$ \\
\hline
\end{tabular}


Some advantages are obtained in managing and accessing administrative appraisal through applications that save on processing time, do not require space for storing assessment instruments and reduces administrative management costs. Accessibility that can be easily understood by users, adds a level of communication between teachers and students in the assessment process.

Communication on Schoology enables students and school to easily communicate, share resources, host collaborative groups, and stay actively engaged from any device. Schoology meets the needs of all teaching styles. Faster access to materials is provided. Teachers can easily create and update course materials. The interface is simple, similar to Facebook, and easy to load. It allows the teacher to monitor the amount of time students spend using Schoology.

Schoology design is equivalent to Facebook where conversations can take place, send messages, update status and other information and media can be shared in class networks. There are two main contexts in schoology, namely interactive communication and the exchange of academic information. The teacher can ask discussion questions, create collaborative groups, or notify assignments between students and their teacher. For example, students who actively participate in reading activities can ask questions and post comments about classmates' book choices. The teacher can participate, monitor, and assess the discussions led by these students. Academic information to students is an aspect that can be used by students. In Schoology, students can access their grades, attendance records, and teacher feedback about tasks that have been delivered electronically. Access to student information and ask students to be responsible for their academic(Manning, C. et al., 2011).

Overall, school design encourages the voluntary use of students which can be done inside and outside the classroom, anytime, anywhere. Teachers can enter teaching and learning, the results of combining teaching in the digital age can help students be more involved in their studies.

Schoology's offer is more than just a social media menu like Facebook. Schoology is a powerful learning management system with applications available for iPad, iPhone, Android and Kindle mobile devices. Activities that can be used by students are sending assignments, taking tests, sending comments, and asking questions and intuitively for them, and they maintain access to their class programs until the semester ends.(Wall, 2014).

\subsection{Management of facilities and infrastructure for the implementation of schoology- based assessments at SMA Negeri 10 Kota Tangerang.}

One of the Learning Management System which has the basic version available free and easy to use because it is similar to social media like Twitter or Facebook is schoology. The menu which Schoology has are Courses, it is a facility to create one course, Group, which is a facility to create community learning, and Resources, which is a facility to save learning materials. In Courses menu, there is quiz menu which has many kinds such as multiple-choice, true-false, matching, and short answer. Making questions in Schoology is equipped with tools Symbol and Equation. All questions with Figure, symbol, and equation could be written on Schoology. Besides, schoology has many features and an interesting layout like online assessment book, attendance list, the remainder of feature user from students (Wahyuni, 2017).

Banefits of schoology can be implemented by a single teacher for their class, with no specialist technical expertise required to get started or signup. Teachers can set up their own classes with Schoology, or multiple teachers can take advantage of free features. It allows lessons and coursework to be easily created, used, and shared and manages academic material through a social networking interface that is similar to Facebook. Schoology is a very secure platform that is built using a cascading set of permissions and privacy settings. Only users with 
a username/email and password have access to the system. All data and information is controlled by a user's unique ID and role. Schoology integrates with AD/LDAP, any third party authentication service, or even external accounts such as Google Apps. The simplest remote authentication involves a token-based single-sign on. It maintains access logs of all user activity. These logs contain a timestamp, IP address, and username as well as a variety of other data that can be used in data analysis and tracking.

\subsection{Impact of the implementation of schoology-based assessments at SMA Negeri 10 Kota Tangerang}

The impact of using schoology consists of schoology can encourage student motivation and create positive attitudes towards learning activities outside the classroom (Low, 2017). The schoology application concludes that teachers can use schoology websites to manage classroom practices every day with the aim of increasing students who are learning. Schoology allows students to monitor their own learning processes and make students responsible for their own understanding and thinking. schoology is highly recommended as a supportive and advanced tool in classroom management and successful teaching (Biswas et al., 2013). The use of schoolbased E-learning media contributes significantly to improve students' learning motivation and learning achievements than the PowerPoint media (Purba, Sipahutar, \& Edi, 2017)

Before implementing schoology, teachers need to be trained to use Schoology, this must occur before teachers are expected to use Schoology in their classrooms. Before implementing schoology, teachers need to be trained to use Schoology, this must occur before teachers are expected to use Schoology in their classrooms.(Schlager, 2016). The Schoology tool allows its users to adapt work and learning pace providing a cognitive challenge and opportunities for deep processing of meaning in learning.(Garcia et al., 2018).

Schoology as an alternative model of learning that can provide additional theoretical material out-side school period. therefore, the face to face meetings to give the theory can be reduced and replaced with practicum. (Irawan et al., 2017). Schoology is an effective means of writing exercise among students when used as a supplement to the traditional method of learning (Sicat, 2015).

\section{CONCLUSION}

Implementing schoology-based assessment at Tangerang City State Senior High School 10 is carried out systematically with media facilities and infrastructure equipped with adequate implementation of schoology-based assessment, the application of schoology systems has a positive impact on the application system-based assessment process for schools, because the assessment process is more effective and efficient.

\section{Acknowledgment}

The authors would like to thank the personnel of Tangerang City State Senior High School 10 and Universitas Islam Syekh-Yusuf Tangerang.

\section{References}

[1] Afandi, Junanto, T., \& Afriani, R. (2016). Implementasi Digital - Age Literacy Dalam Pendidikan Abad 21 Di Indonesia, 113-120.

[2] Aminoto, T., \& Pathoni, H. (2014). Penerapan Media E-Learning Berbasis Schoology Untuk Meningkatkan Aktivitas dan Hasil Belajar Materi Usaha dan Energi Di Kelas XI SMA N 10 Kota 
Jambi. Jurnal Sainmatika, 8, 13-29.

[3] Basori. (2007). Pemanfaatan Social Learning Network "Edmodo" Dalam Membantu Perkuliahan Teori Bodi Otomotif Di Prodi PTM JPTK FKIP UNS, (271).

[4] Biswas, S., Parsons, J., Cowin, K. M., Keiser, D. L., Antonio, M. C. K., Schilling, M., ... Petersen, N. J. (2013). Northwest Journal of, 11(2), 1-196.

[5] Farmington Schoology. (2018). What is schoology. Retrieved April 25, 2018, from https://sites.google.com/site/farmingtonschoology/what-is-schoology

[6] Firmansyah, B. H. (2015). Pengembangan Blended Learning Berbasis Schoology Beny Hari Firmansyah.

[7] Garcia, L. F. S., Amat, S. S., Garcia, N. M., \& Colomina, S. S. (2018). Schoology as an alternative to traditional teaching tools for university students Schoology As An Alternative To Traditional Teaching Tools For University Students, (July). https://doi.org/10.21125/edulearn.2018.1754

[8] Irawan, V. T., Sutadji, E., \& Widiyanti. (2017). Blended learning based on schoology: Effort of improvement learning outcome and practicum chance in vocational high school. Cogent Education, 4(1), 1-10. https://doi.org/10.1080/2331186X.2017.1282031

[9] Low, P. (2017). E-learning Implementation in Foundation English Class : Learners' Perspectives and Learning Achievement, 9(4). https://doi.org/10.7763/IJCTE.2017.V9.1153

[10] Manning, C., Brooks, W., Crotteau, V., Diedrich, A., Moser, J., \& Zwiefelhofer, A. (2011). Tech Tools for Teachers, By Teachers: Bridging Teachers and Students. Wisconsin English Journal, 53(1), 24-28. Retrieved from http://journals.library.wisc.edu/index.php/wej/article/viewFile/379/444

[11] Purba, A., Sipahutar, H., \& Edi, S. (2017). Comparison of Motivation and Student s ' Learning Achievements by using E-Learning based Schoology and Power Point on Biology Material, 4(11), 208-213.

[12] Sarrab, M., Elbasir, M., \& Alnaeli, S. (2016). Computers in Human Behavior Towards a quality model of technical aspects for mobile learning services : An empirical investigation. Computers in Human Behavior, 55, 100-112. https://doi.org/10.1016/j.chb.2015.09.003

[13] Schlager, D. (2016). Schoology: The Adoption of a Learning Management System Schoology: The Adoption of a Learning Management System.

[14] Sicat, A. S. (2015). Enhancing College Students' Proficiency in Business Writing Via Schoology. International Journal of Education and Research, 3(1), 159-178. Retrieved from http://www.ijern.com/journal/2015/January-2015/14.pdf

[15] Sohibun, \& Ade, F. Y. (2017). Pengembangan Media Pembelajaran Berbasis Virtual Class Berbantuan Google Drive, 2(2), 121-129. https://doi.org/10.24042/tadris.v2i2.2177

[16] Ulva, N. L., Kantun, S., \& Widodo, J. (2017). Penerapan E-Learning Dengan Media Schoology Untuk Meningkatkan Motivasi Dan Hasil Belajar Siswa Pada Kompetensi Dasar Mendeskripsikan Konsep Badan Usaha Dalam, 11, 96-102. https://doi.org/10.19184/jpe.v11i2.6453

[17] Wahyuni, S. (2017). Jurnal Pendidikan IPA Indonesia Design And Implementation Of SchoologyBased Blended, 6(1), 170-178. https://doi.org/10.15294/jpii.v6i1.7205

[18] Wall, A. (2014). Schoology in higher education: embracing the Facebook factor. Retrieved May 2, 2018, from https://secure.onlinelearningconsortium.org/conference/2014/et4online/schoologyhigher-education-embracing-facebook-factor

[19] Warsito, M. B., \& Djuniadi. (2016). Pengembangan E-Learning berbasis Schoology pada, 4(1), 91-99. 